\title{
Access to highly substituted oxazoles by the reaction of $\alpha$-azidochalcone with potassium thiocyanate
}

\author{
Mysore Bhyrappa Harisha ${ }^{\ddagger 1,2}$, Pandi Dhanalakshmi ${ }^{\ddagger 1,3}$, Rajendran Suresh ${ }^{1}$, \\ Raju Ranjith Kumar ${ }^{1}$ and Shanmugam Muthusubramanian ${ }^{* 1}$
}

\author{
Full Research Paper \\ Address: \\ ${ }^{1}$ Department of Organic Chemistry, School of Chemistry, Madurai \\ Kamaraj University, Madurai-625 021, Tamil Nadu, India, \\ 2Eurofins-Advinus Limited, Phase II, Peenya Industrial Area, \\ Bangalore-560 058, India and ${ }^{3}$ Department of Inorganic and Physical \\ Chemistry, Indian Institute of Science (IISc), Bangalore-560 012, India \\ Email: \\ Shanmugam Muthusubramanian* - muthumanian2001@yahoo.com \\ * Corresponding author $\ddagger$ Equal contributors \\ Keywords: \\ aminothiazole; oxazole; potassium persulfate; thiazole; vinyl azide
}

Beilstein J. Org. Chem. 2020, 16, 2108-2118. https://doi.org/10.3762/bjoc. 16.178

Received: 02 July 2020

Accepted: 21 August 2020

Published: 31 August 2020

Associate Editor: T. J. J. Müller

(C) 2020 Harisha et al.; licensee Beilstein-Institut. License and terms: see end of document.

\section{Abstract}

The reactivity of $\alpha$-azidochalcones has been explored for the preparation of highly substituted oxazoles via a $2 H$-azirine intermediate. The azidochalcones, when treated with potassium thiocyanate in the presence of potassium persulfate, lead to 2,4,5-trisubstituted oxazoles in good yields. Incidentally, 2-aminothiazoles are the products when ferric nitrate is employed instead of persulfate in the above reaction.

\section{Introduction}

Vinyl azide is one of the most versatile and potent building blocks explored in the synthesis of several heterocycles [1-5]. It can undergo photolysis or thermolysis to afford highly strained three-membered $2 \mathrm{H}$-azirine, which can act as the precursor for nitrogen heterocycles. As a part of our synthetic design towards the construction of five-membered heterocycles, we have previously reported the synthesis of highly substituted imidazoles [6], indoles [7] and pyrroles [8] starting from different azidochalcones. In continuation, employing $\alpha$-azidochalcones as the precursor [9], we herein report the preparation of highly substituted oxazoles and thiazoles.
Oxazoles are ubiquitously found in various natural products [10-14], pharmaceuticals [15-18], functional materials [19,20] as well as in several organic building blocks [21-26]. Some oxazoles play a significant role in biological properties such as TRPV1 antagonistical activity, antifungal, analgesic, antiinflammatory, antiproliferative, antileukemia, anticancer [2732] and enzyme inhibitory activities [33-42]. 2,4,5-Trisubstituted oxazoles are embedded in some natural products and pharmaceuticals with a broad range of biological activities prompting the development of efficient synthetic strategies for this useful heterocycle [43,44] (Figure 1). 
<smiles>O=C(O)CCc1nc(-c2ccccc2)c(-c2ccccc2)o1</smiles>

oxaprozin<smiles>Nc1nc(N)c(-c2ccccc2)s1</smiles>

amiphenazol<smiles>COC(Cc1ccc(OCCc2nc(-c3ccccc3)oc2C)c2ccsc12)C(=O)O</smiles>

aleglitazar<smiles>Nc1ccc(S(=O)(=O)Nc2nccs2)cc1</smiles>

sulfathiazole<smiles>Cc1nc(C2CCCCC2)c(-c2ccc(S(N)(=O)=O)c(F)c2)o1</smiles>

JTE $=522:$ COX-2 inhibitor

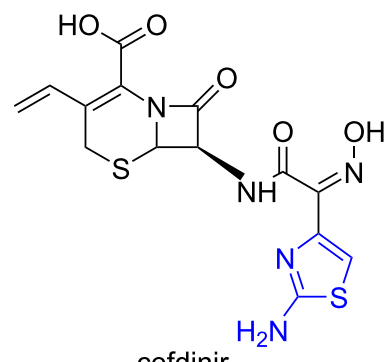

Figure 1: Examples of biologically active oxazole and aminothiazole scaffolds.

In the recent past, the readily accessible $2 H$-azirine, an efficient source of nitrogen, was employed as starting material for the synthesis of oxazole with various coupling partners such as aldehyde, trifluoroacetic acid, etc. [8,45-50] (Scheme 1).

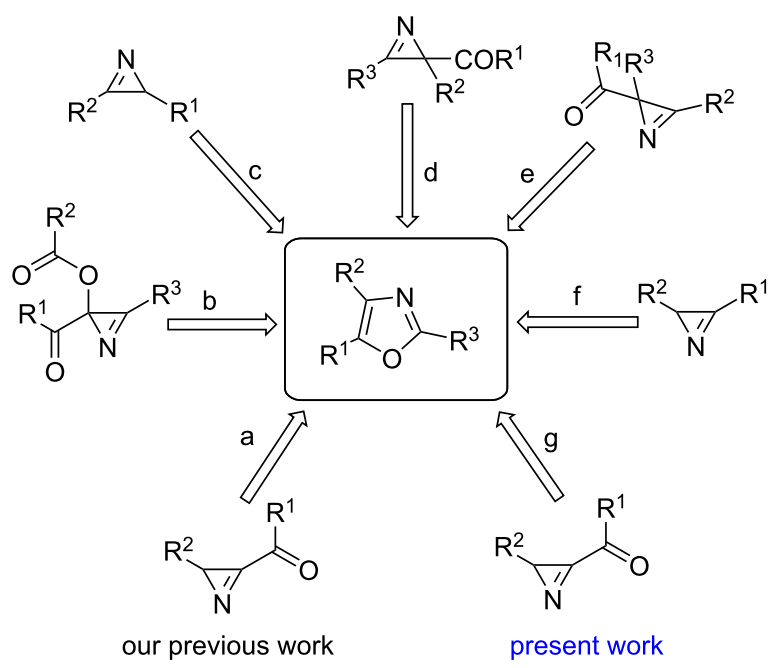

Scheme 1: Strategies for the synthesis of 2,4,5-trisubstituted oxazole from azirine. a) $\mathrm{I}_{2}, \mathrm{PPh}_{3}$; b) $\mathrm{NaH}, 1 \mathrm{H}$-pyrazole; c) 2-bromoacetyl bromide, $\mathrm{NaN}_{3}$; d) heating; e) $t$ - $\mathrm{BuOK}$; f) $\mathrm{Ph}-\mathrm{CHO}$, visible light; g) $\mathrm{KSCN}, \mathrm{K}_{2} \mathrm{~S}_{2} \mathrm{O}_{8}$.

Thiazole is a common structural motif that is found in a wide variety of naturally existing alkaloids and a number of pharmaceutically active compounds [51-53]. 2-Aminothiazole has a thiourea-like character with a tendency to modulate promiscuously multiple biological targets. Thiazole derivatives also exhibit a broad spectrum of biological activities including antiviral, antiprion, anti-inflammatory, antimicrobial, anituber- cular, psychotropic and anticancer [54-60]. The marketed cancer drug dasatinib [61] continues to prove its worth.

In this work, it is shown that highly substituted oxazoles and aminothiazoles could be accessed directly from the reaction of substituted $\alpha$-azidochalcones with potassium thiocyanate. Thiocyanate is a known ambident reagent with two potential sites of attack, enabling the selective and efficient construction of $\mathrm{C}-\mathrm{C}$ and $\mathrm{C}-\mathrm{N}$ bonds towards biologically important heterocyclic skeletons [62-64].

\section{Results and Discussion}

Previously, we have reported the TMSOTf-catalyzed synthesis of highly substituted imidazoles from $\alpha$-azidochalcones under mild conditions [65]. As a sequel, the synthesis of oxazoles with an arylimino substituent has been accomplished in this work. The biologically important arylimino group [66-69] integrated with a highly substituted oxazole skeleton with a thiol group is expected to have potential synergetic bioactivity [70].

During the exploration of the reactivity of azidochalcones with thiocyanate in the presence of the oxidizing agent, $\mathbf{1 i}$ was chosen as the model $\alpha$-azidochalcone to react with potassium thiocyanate $\mathbf{2}$ in the presence of several oxidants and metal salts (Table 1). The initial attempts employing iodine, CAN and $\mathrm{ZnCl}_{2}$ upon refluxing in acetonitrile for 6 hours did not yield any product (Table 1, entries 1, 2 and 4).

When potassium persulfate $\left(\mathrm{K}_{2} \mathrm{~S}_{2} \mathrm{O}_{8}\right)$ is employed, highly substituted oxazole $3 \mathbf{i}$ has been obtained. With the observation that potassium persulfate can efficiently catalyze the reaction to furnish highly substituted oxazole $\mathbf{3 i}$, we carried out the reac- 
Table 1: Optimisation studies. ${ }^{a}$

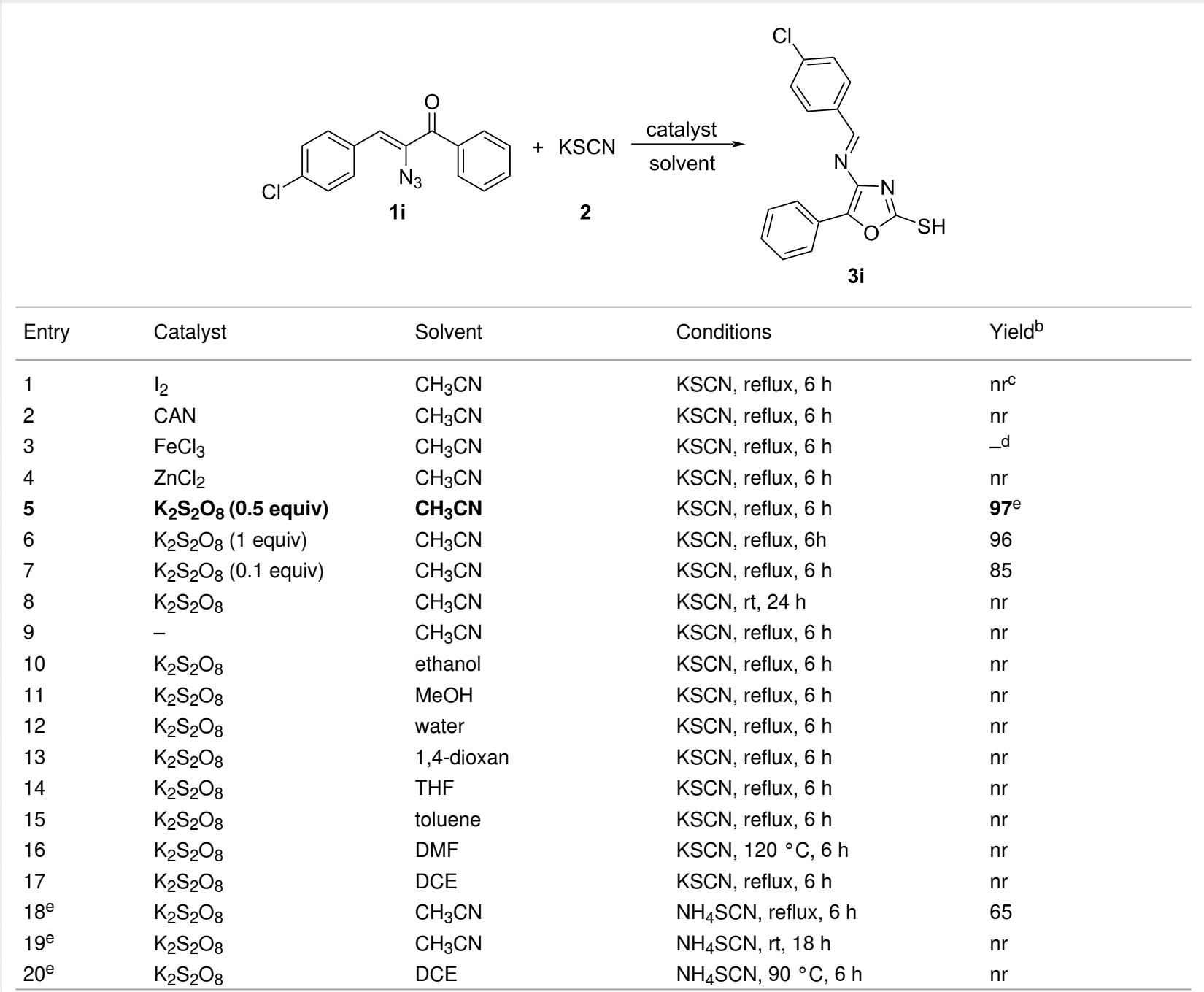

aReaction conditions: $\alpha$-azidochalcone 1 (1 equiv), potassium thiocyanate 2 ( 3 equiv), oxidant/metal salt ( 0.5 equiv) in various solvents ( $2 \mathrm{~mL}$ );

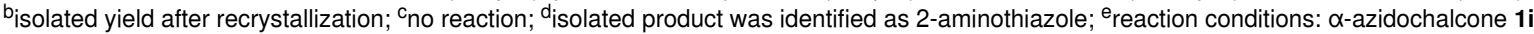
(1 equiv), ammonium thiocyanate 2 a (2 equiv), potassium persulfate ( 0.5 equiv) solvent $(2 \mathrm{~mL})$.

tion of $\mathbf{1 i}$ and $\mathbf{2}$ in acetonitrile in the presence of various equivalents of potassium persulfate, in an attempt to evaluate the catalytic efficiency of persulfate. The reaction was found occurring most efficiently with 1 equiv of $\mathbf{1 i}, 3$ equiv of potassium thiocyanate 2 , and 0.5 equiv of potassium persulfate with a yield of $97 \%$ of $3 \mathbf{i}$. The yellow solid obtained after filtration of the reaction mixture afforded pure product $3 \mathbf{i}$ without the requirement of any further work-up or purification protocol. The analytically pure sample was obtained by recrystallization from cold diethyl ether. However, in the absence of potassium persulfate (Table 1, entry 9), no product was observed indicating that potassium persulfate is essential to facilitate the reaction. After determining the optimal amount of persulfate, we have examined various solvents (Table 1, entries 10-17) to study the outcome of the reaction. These solvent screening studies indi- cated that acetonitrile is a suitable solvent for this reaction. Having established conditions for the high-yielding synthesis of oxazole 3 , the scope of this transformation with various $\alpha$-azidochalcones was explored (Scheme 2).

As shown in Scheme 2, an efficient conversion of $\alpha$-azidochalcones 1a-u to highly substituted functionalized oxazoles $\mathbf{3 a}-\mathbf{u}$ has been achieved with both electron-poor and electron-rich aryl substituents. Both nitro- and bromo-substituted systems can be further functionalized to get a new set of products. The tolerance of the reaction for a variety of aryl substituents illustrates the generality of this method for the preparation of a range of highly substituted oxazoles. Further, the scalability of the reaction using an optimized protocol was investigated by conducting the reaction on a multigram scale (Scheme 3). It was found 


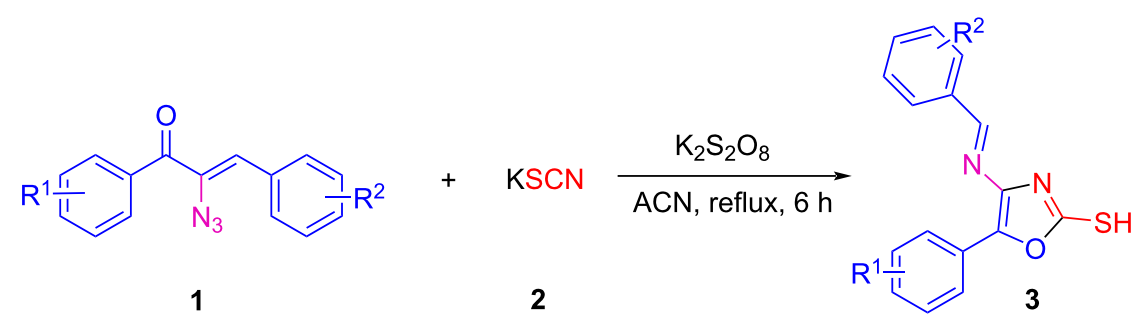

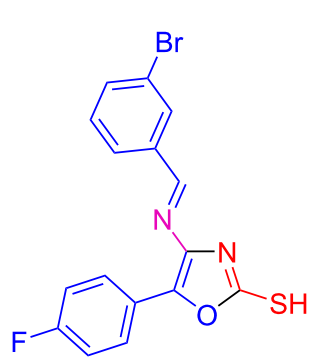

$3 a, 90 \%$

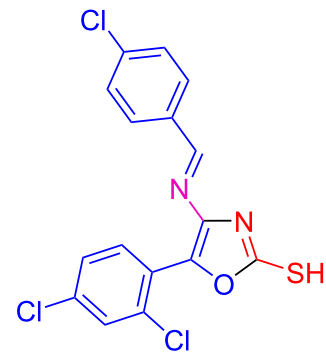

3b, $89 \%$

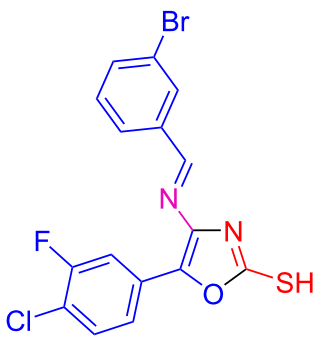

3c, $92 \%$<smiles>N=Cc1ccc(Cl)cc1Cl</smiles>

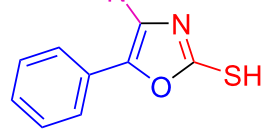

3d, $93 \%$

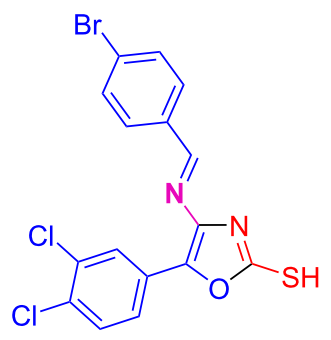

$3 e, 89 \%$<smiles>Sc1nc(/C=N/c2ccc(Cl)cc2Cl)oc1-c1ccc(Cl)cc1</smiles>

3f, $93 \%$<smiles>Fc1ccc(-c2oc(S)nc2/N=C/c2ccc(Cl)cc2Cl)cc1</smiles>

$3 g, 90 \%$<smiles>Fc1ccc(-c2oc(S)nc2/N=C/c2ccc(Cl)cc2Cl)cc1Cl</smiles>

3h, $92 \%$<smiles>N=Cc1ccc(Cl)cc1</smiles><smiles>Nc1nc(S)oc1-c1ccccc1</smiles>

$3 i, 97 \%$

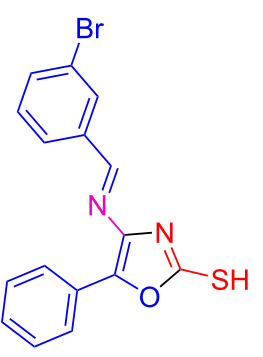

3j, 91\%<smiles>Cc1ccc(-c2oc(S)nc2/N=C/c2ccc(Cl)cc2Cl)cc1</smiles><smiles>N#Cc1ccc(Cl)cc1</smiles><smiles>Sc1nc(/N=C/c2cccc(Br)c2)c(-c2ccc(Cl)cc2Cl)o1</smiles>

$\mathrm{MeO}$<smiles>COc1ccc(C=Nc2nc(S)oc2-c2ccc(Cl)cc2Cl)cc1</smiles>

3k, $95 \%$

3I, $87 \%$

3m, 93\%

3n, $90 \%$

$30,88 \%$<smiles>Cc1cc(-c2oc(S)nc2N=Cc2ccc(Cl)cc2Cl)c(-c2oc(S)nc2N=Cc2cccc([N+](=O)[O-])c2)cc1-c1ccc(F)cc1</smiles>

$3 p, 92 \%$

$3 q, 90 \%$

3r, 93\%

3s, $89 \%$

3t, $85 \%$

$3 u, 92 \%$ 


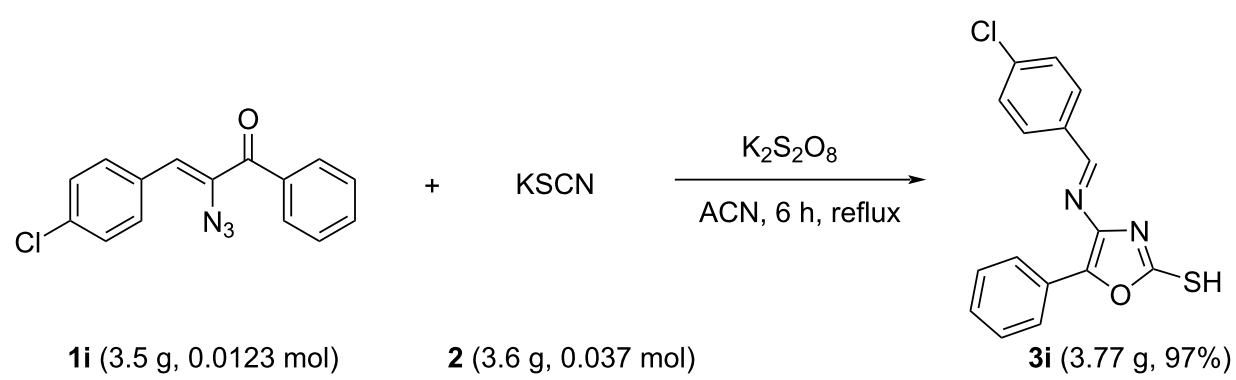

Scheme 3: Large-scale synthesis of 3i.

that the reaction between $\mathbf{1 i}$ and $\mathbf{2}$ on a multigram scale proceeded to afford $\mathbf{3 i}$ in $97 \%$ yield.

In Figure 2, photograph a shows the reaction mixture just at the start of the reaction and $b$ is the photograph after the completion of the reaction.

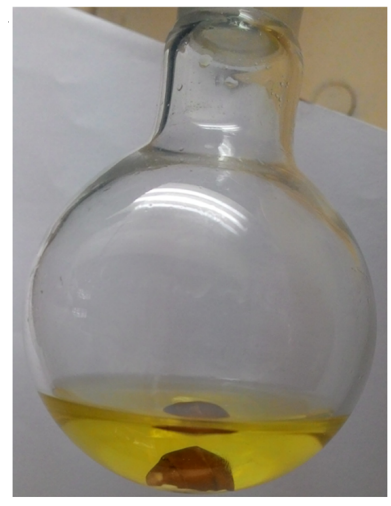

$\mathbf{a}$

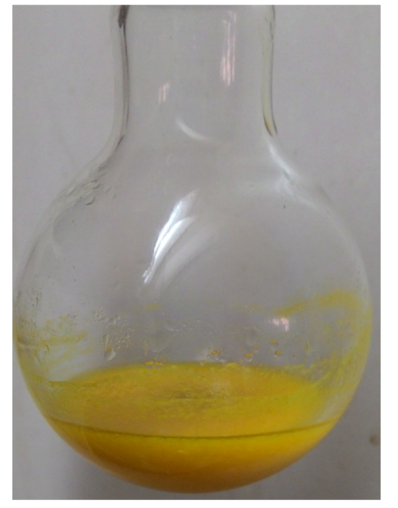

b
Figure 2: Large-scale synthesis of $\mathbf{3 i}$. a) At the start of the reaction, b) after the reaction.

Further, the utility of the thiol group in $\mathbf{3}$ for the generation of a library of compounds was demonstrated by the simple acetylation and alkylation (Scheme 4 and Scheme 5). The acetylation of the thiol group in $\mathbf{3 d}$ proceeded smoothly with acetyl chloride in the presence of sodium hydride to afford $\mathbf{5}$ in good yield.
The structure of the product and the site of acetylation was confirmed by X-ray crystallography of a single crystal of 5 [71] (Figure 3).

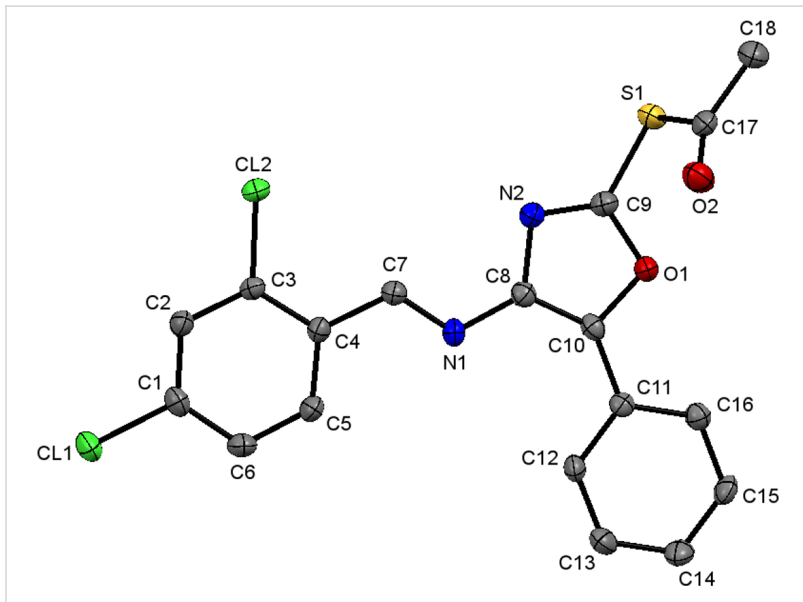

Figure 3: ORTEP diagram of compound $\mathbf{5}$.

The methylated and benzylated derivatives 6 and 7 were also obtained from $\mathbf{3 m}$. S-Methylation of $\mathbf{3 m}$ was achieved in $91 \%$ yield with methyl iodide in the presence of NaH/THF and the S-benzylation has been carried out by a similar procedure (Scheme 5).

To derive the mechanism of the reaction, a few control experiments have been executed (Scheme 6). Initially, the reaction of

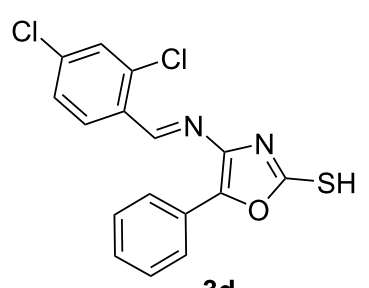

$3 d$

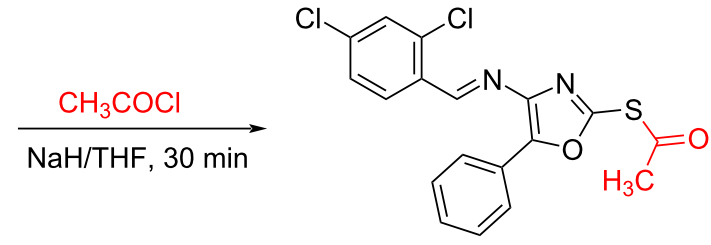

5: $77 \%$ 


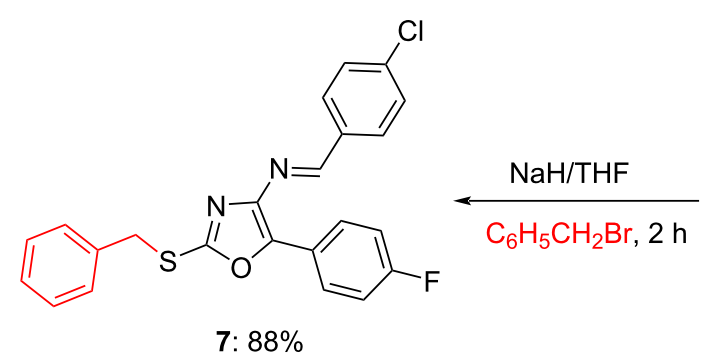<smiles>Fc1ccc(-c2oc(S)nc2/N=C/c2ccc(Cl)cc2)cc1</smiles><smiles>Cc1nc(/N=C/c2ccc(Cl)cc2)c(-c2ccc(F)cc2)o1</smiles>

$3 m$

6: $91 \%$

Scheme 5: Synthesis of S-methyl/benzylated products 6 and 7 .

with radical scavanger

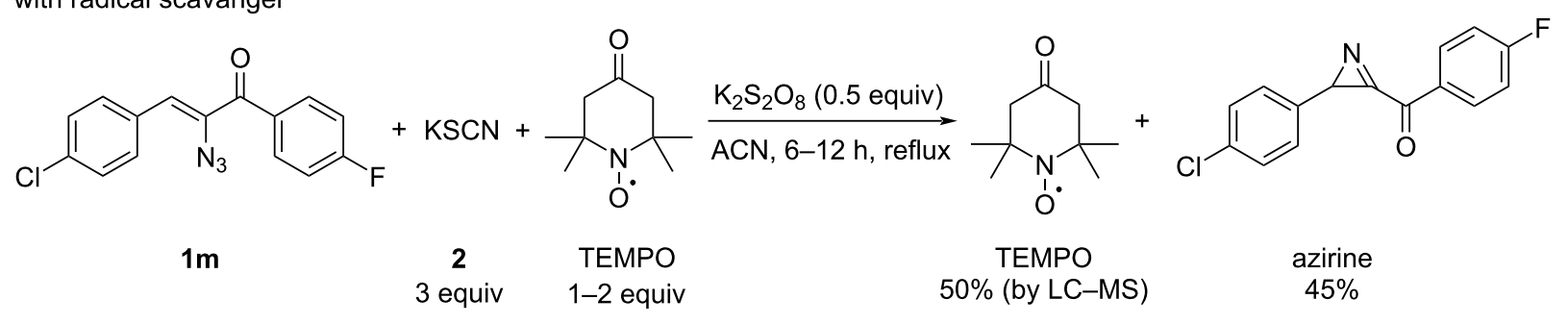<smiles>Cc1cc(C(C)(C)C)c(O)c(C(C)(C)C)c1</smiles>

without $\mathrm{K}_{2} \mathrm{~S}_{2} \mathrm{O}_{8}$

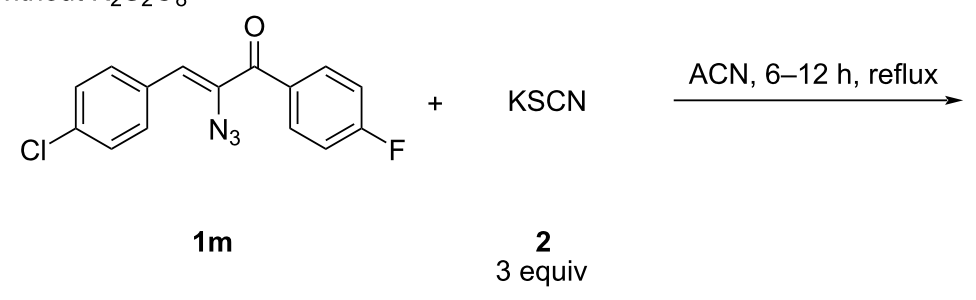<smiles>O=C(C1=NC1c1ccc(Cl)cc1)c1ccc(F)cc1</smiles>

only azirine (by LC-MS)

Scheme 6: Control experiments.

1m with potassium thiocyanate $\mathbf{2}$ under the optimal conditions in the presence of TEMPO furnished azirine and TEMPO, while the same reaction in the presence of BHT afforded the BHTcoupled thiocyanate product (SO-(2,6-di-tert-butyl-4-methylphenyl) (thioperoxocyanate)). These observations unambiguously indicate that the reaction proceeds through a radical pathway. Potassium persulfate helps to generate a thiocyanate radical and in the absence of potassium persulfate the reaction did not proceed. This experiment supports the role of potassium persulfate as an oxidant.

Based on these experiments, the following plausible mechanism for the formation of 2,4,5-trisubstituted oxazoles can be proposed (Scheme 7). It is known that the thiocyanate radical is generated from potassium thiocyanate by the reaction with potassium persulfate [72]. The $\mathrm{N}$-end of thiocyanate radical reacts with the $\mathrm{C}=\mathrm{N}$ bond to give the intermediate $\mathbf{A}$ which undergoes homolytic cleavage yielding B. Subsequent cyclisation results in the oxazole ring.

During these optimization trials, it was interesting to note the formation of 2-aminothiazole, when ferric chloride was employed along with thiocyanate (Table 1 , entry 3 ). There is a report pertaining to this transformation with $\mathrm{Fe}(\mathrm{II})$ salts [73]. We further wanted to capitalize on this result and optimize the methodology to access a series of 2-aminothiazoles as the re- 


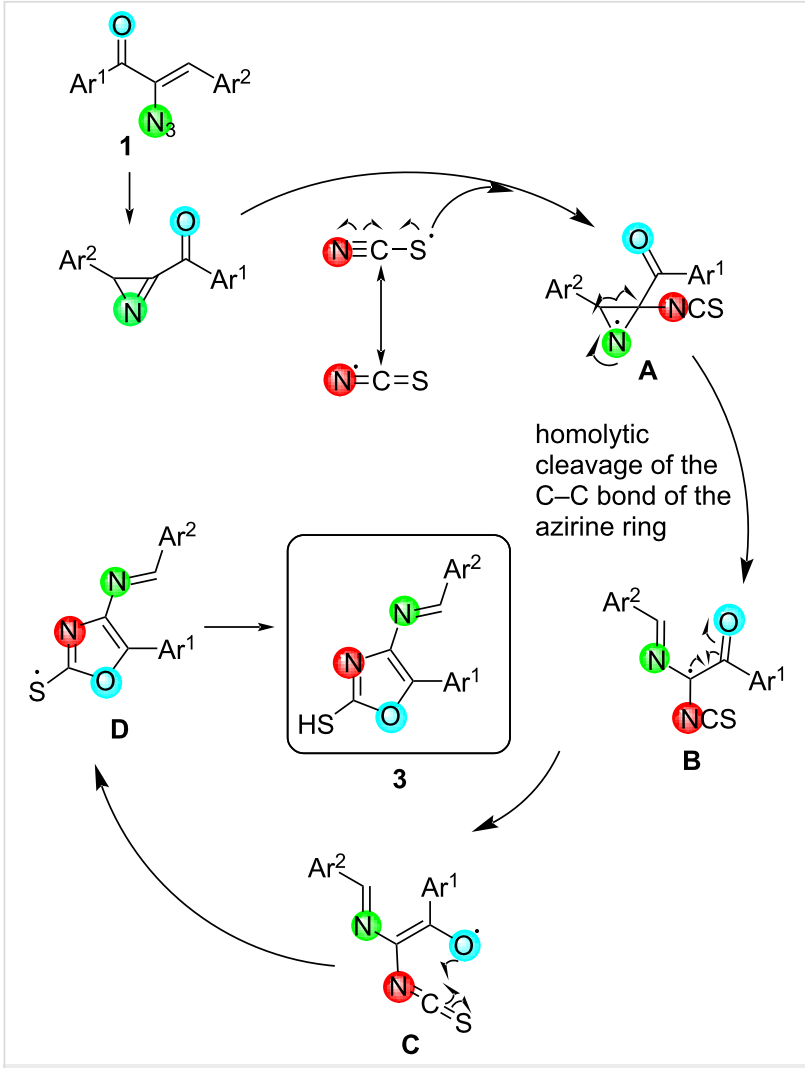

Scheme 7: Plausible mechanism proposed for the formation of 2,4,5trisubstituted oxazoles 3 . ported methods [74-79] to access 2,4,5-trisubstituted aminothiazoles, especially 4-aroyl-2-amiothiazoles, suffered from low yields, harsh reaction conditions, expensive and detrimental metal precursors as well as the pollution concerning $\alpha$-halocarbonyl compounds.

Initially, we started the reaction with (Z)-2-azido-1,3-bis(4chlorophenyl)prop-2-en-1-one (1d) and commercially available potassium thiocyanate (2) as a representative model system. To optimize the best reaction condition, we began this study by performing the reaction with ferric chloride in acetonitrile at $80{ }^{\circ} \mathrm{C}$ for $6 \mathrm{~h}$ (Table 2, entry 1 ).

This reaction has led to the exclusive formation of 4,5disubstituted 2-aminothiazole 4d. The catalytic activities of different $\mathrm{Fe}(\mathrm{III})$ salts and the solvents were screened in the reaction. When ferric chloride was employed in DCE or toluene, the expected product was not obtained (Table 2, entries 2 and 3 ). The reaction failed to proceed in acetonitrile at room temperature also (Table 2, entry 4). As a further variation, we examined $\mathrm{Fe}_{2} \mathrm{O}_{3}$ as catalyst in acetonitrile which resulted only in $10 \%$ conversion (Table 2 , entry 5). Further screening was performed with ferric nitrate and the 2-aminothiazole was obtained in $60 \%$ yield (Table 2 , entry 6). The product was obtained in excellent yield when the reaction mixture was heated for $6 \mathrm{~h}$ (Table 2, entry 7). Potas-

Table 2: Screening of iron salts and solvents ${ }^{a}$.<smiles>NC(=Cc1ccc(Cl)cc1)C(=O)c1ccc(Cl)cc1</smiles>

\begin{tabular}{llllll}
\hline Entry & Solvent & Catalyst & Temp & Time $[\mathrm{h}]$ & Yield $^{\mathrm{b}}[\%]$ \\
\hline 1 & $\mathrm{CH}_{3} \mathrm{CN}$ & $\mathrm{FeCl}_{3}$ & reflux & 6 & 85 \\
2 & $\mathrm{DCE}$ & $\mathrm{FeCl}_{3}$ & reflux & 5 & $\mathrm{nr}$ \\
3 & toluene & $\mathrm{FeCl}_{3}$ & reflux & 5 & $\mathrm{nr}$ \\
4 & $\mathrm{FeCl}_{3} \mathrm{CN}$ & rt & 18 & $\mathrm{nr}$ \\
5 & $\mathrm{CH}_{3} \mathrm{CN}$ & $\mathrm{Fe}_{2} \mathrm{O}_{3}$ & reflux & 6 & 10 \\
6 & $\mathrm{CH}_{3} \mathrm{CN}$ & $\mathrm{Fe}\left(\mathrm{NO}_{3}\right)_{3}$ & reflux & 3 & 60 \\
7 & $\mathrm{CH}_{3} \mathrm{CN}$ & $\mathrm{Fe}\left(\mathrm{NO}_{3}\right)_{3}$ & reflux & 6 & 93 \\
8 & $\mathrm{DCE}$ & $\mathrm{Fe}\left(\mathrm{NO}_{3}\right)_{3}$ & reflux & 6 & $\mathrm{nr}$ \\
9 & $\mathrm{THF}$ & $\mathrm{Fe}\left(\mathrm{NO}_{3}\right)_{3}$ & reflux & 6 & $\mathrm{nr}$ \\
10 & $\mathrm{CH} \mathrm{H}_{3} \mathrm{CN}$ & $\mathrm{K}(\mathrm{Fe})(\mathrm{CN})_{6}$ & reflux & 6 & $\mathrm{nr}$ \\
\hline
\end{tabular}

aReaction conditions: azidochalcone 1 ( 1 equiv), potassium thiocyanate 2 ( 3 equiv), $\mathrm{Fe}(\mathrm{III})$ ( 0.5 equiv), solvent $(2 \mathrm{~mL}){ }^{\mathrm{b}}$ Isolated yield after column chromatography. 
sium ferricyanide has also been proved ineffective (Table 2, entry 10).

Using the optimized experimental conditions, the Fe(III)-mediated formation of 4,5-disubstituted 2-aminothiazoles 4 was examined for the substrate scope (Scheme 8).

All the synthesized compounds $\mathbf{4 a}-\mathbf{l}$ were confirmed by $1 \mathrm{D}$ and 2D NMR, IR spectroscopy and HRMS techniques. Additional evidence of the structures of these compounds was obtained based on the single-crystal X-ray analysis of 4h [71] (Figure 4).

The nitrogen end of the thiocyanate attacks the azirine to form the oxazole ring and the sulfur end of the thiocyanate involves in the reaction resulting in the 2-aminothiazole ring. The mech-

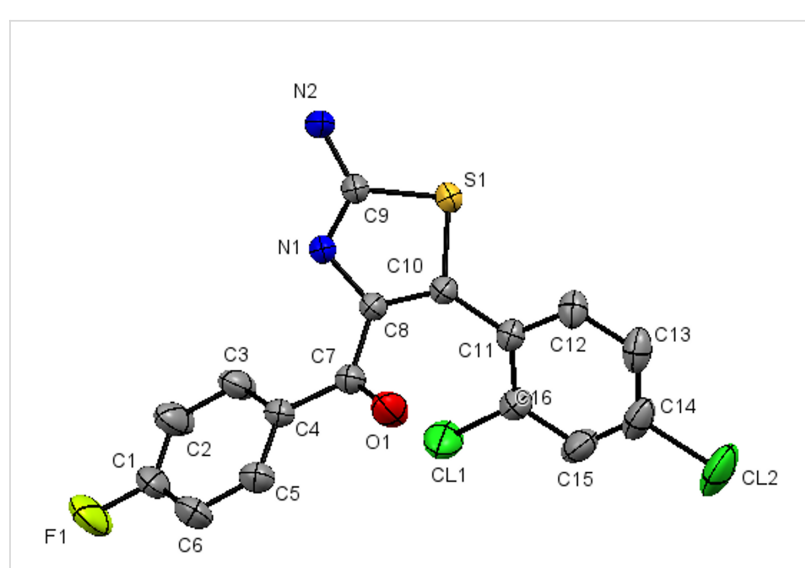

Figure 4: X-ray crystal structure of $\mathbf{4 h}$.

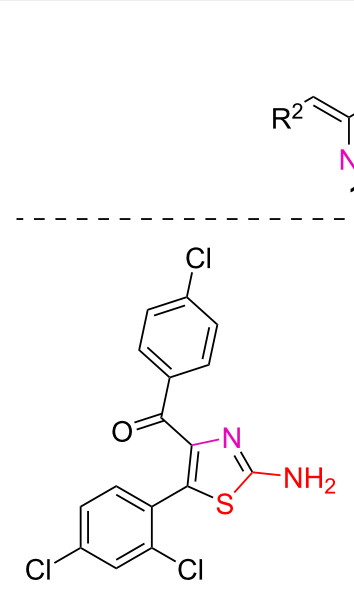

4a, $92 \%$<smiles>Nc1nc(C(=O)c2ccc(F)cc2)c(-c2cccc(Br)c2)s1</smiles>

4 e, $83 \%$<smiles>Nc1nc(C(=O)c2ccc(Cl)c(Cl)c2)c(-c2ccc(Br)cc2)s1</smiles>

4i, $93 \%$<smiles>Nc1nc(C(=O)c2ccccc2)c(-c2ccc(Cl)cc2)s1</smiles>

4f, $89 \%$<smiles>Nc1nc(C(=O)c2ccc(F)c(Cl)c2)c(-c2ccc(Cl)cc2Cl)s1</smiles>

$4 j, 82 \%$

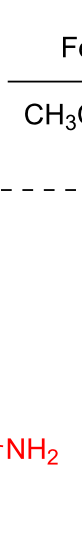

$\mathrm{H}_{3} \mathrm{CN}$, reflux, $6 \mathrm{~h}$<smiles>[R1]C(=O)c1nc(N)s[R4]1[H]</smiles>

4<smiles>Nc1nc(C(=O)c2ccccc2)c(-c2cccc(Br)c2)s1</smiles><smiles>Nc1nc(C(=O)c2ccccc2)c(-c2ccc(Cl)cc2Cl)s1</smiles>

4g, $87 \%$<smiles>Nc1nc(C(=O)c2ccc(F)c(Cl)c2)c(-c2cccc(Br)c2)s1</smiles>

4k, $81 \%$<smiles>Nc1nc(C(=O)c2ccc(Cl)cc2)c(-c2ccc(Cl)cc2)s1</smiles>

4d, $93 \%$

4h, $88 \%$<smiles>Nc1nc(C(=O)c2ccc(F)cc2)c(-c2ccc(Cl)cc2)s1</smiles>

4I, $91 \%$

Scheme 8: Reaction of vinyl azide 1 and $\mathbf{3}$ with ferric nitrate. Reactions were carried out at reflux temperature, using 1 (1 mmol), 2 ( 3 mmol), ferric nitrate $(0.5 \mathrm{mmol})$ in acetonitrile $(2 \mathrm{~mL})$ for $6 \mathrm{~h}$. Yields refer to the pure products after column chromatography. 
anism for the formation of $\mathbf{4}$ may be similar to that suggested earlier [73].

\section{Conclusion}

In conclusion, we have demonstrated selective routes for the synthesis of highly substituted oxazoles and 2-aminothiazoles from $\alpha$-azidochalcones and potassium thiocyanate employing potassium persulfate and ferric nitrate, respectively. This new route gains a streamlined workup and the elimination of airsensitive techniques to afford the product in good yield in a greener medium over a short time frame. The current method involves a broad substrate scope, excellent functional group tolerance and leaves the active site for further synthetic transformation. The overall strategy allows the generation of new $\mathrm{C}-\mathrm{N}$ and $\mathrm{C}-\mathrm{O}$ bonds in one-pot.

\section{Experimental}

General considerations: The melting points reported in the work are uncorrected. Unless stated otherwise, solvents and chemicals were obtained from commercial sources and used without further purification. Infrared spectra were recorded on a Perkin Elmer instrument with neat sample and only major peaks are reported in $\mathrm{cm}^{-1}$. The ${ }^{1} \mathrm{H}$ and ${ }^{13} \mathrm{C}$ NMR spectra of the new compounds were measured at $400 \mathrm{MHz}$ and $100 \mathrm{MHz}$, respectively, using Bruker and JEOL NMR instruments in DMSO- $d_{6}$. Chemical shifts are reported in parts per million $(\delta)$, coupling constants ( $J$ values) are reported in $\operatorname{Hertz}(\mathrm{Hz})$ relative to tetramethylsilane. Spin multiplicities are indicated by the following symbols: s (singlet), d (doublet), $\mathrm{t}$ (triplet), m (multiplet), dd (doublet of doublets), td (triplet of doublets), ddd (doublet of doublets of doublets), bs (broad singlet). Mass spectra were measured with Micromass Q-Time of flight (HRESIMS).

General procedure for the preparation of 3: To a solution of azidochalcone 1 ( $1 \mathrm{mmol})$ in dry acetonitrile $(2 \mathrm{~mL})$ were added potassium thiocyanate $2(3 \mathrm{mmol})$ and potassium persulfate $(0.5 \mathrm{mmol})$. The mixture was stirred magnetically at reflux temperature for 6 hours under nitrogen atmosphere. After completion of the reaction (monitored by TLC), the solid that separated was filtered, washed with water and acetonitrile and recrystallized with cold diethyl ether to obtain pure yellow product 3 .

General procedure for the preparation of 4: To a solution of azidochalcone 1 (1 mmol) in dry acetonitrile $(2 \mathrm{~mL})$ were added potassium thiocyanate $2(3 \mathrm{mmol})$ and ferric nitrate $(0.5 \mathrm{mmol})$. The reaction mixture was stirred magnetically at reflux for $6 \mathrm{~h}$. After completion of the reaction (monitored by TLC), the product was diluted with water, extracted with ethyl acetate $(15 \mathrm{~mL})$ and purified by column chromatography (100-200 mesh silica gel) using ethyl acetate/petroleum ether mixture to afford product 4 .

\section{Supporting Information}

\section{Supporting Information File 1}

Full experimental details, compound characterisation, and copies of NMR spectra.

[https://www.beilstein-journals.org/bjoc/content/ supplementary/1860-5397-16-178-S1.pdf]

\section{Funding}

M. B. H. is grateful to Eurofins-Advinus Limited, Bangalore for support. P. D. thanks the Science and Engineering Research Board (SERB), India, for a National Post-Doctoral Fellowship (FILE NO.PDF/2018/000099). S. M. thanks CSIR, New Delhi for the award of Emeritus Scientist Scheme (21(1030)/16/EMRII dated 18-11-2016).

\section{ORCID ${ }^{\circledR}$ iDs}

Mysore Bhyrappa Harisha - https://orcid.org/0000-0003-4143-3673 Pandi Dhanalakshmi - https://orcid.org/0000-0001-8132-2906 Raju Ranjith Kumar - https://orcid.org/0000-0002-9926-7770

\section{References}

1. L'abbé, G. Angew. Chem., Int. Ed. Engl. 1975, 14, 775-782. doi:10.1002/anie.197507751

Angew. Chemie. 1975, 87, 831-838. doi:10.1002/ange.19750872304

2. Chiba, S. Chimia 2012, 66, 377-381. doi:10.2533/chimia.2012.377

3. Jung, N.; Bräse, S. Angew. Chem., Int. Ed. 2012, 51, 12169-12171. doi:10.1002/anie.201206409

Angew. Chem. 2012, 124, 12335-12337. doi:10.1002/ange.201206409

4. Hayashi, H.; Kaga, A.; Chiba, S. J. Org. Chem. 2017, 82, 11981-11989. doi:10.1021/acs.joc.7b02455

5. Hu, B.; DiMagno, S. G. Org. Biomol. Chem. 2015, 13, 3844-3855. doi:10.1039/c5ob00099h

6. Rajaguru, K.; Suresh, R.; Mariappan, A.; Muthusubramanian, S.; Bhuvanesh, N. Org. Lett. 2014, 16, 744-747. doi:10.1021/ol403456b

7. Rajaguru, K.; Mariappan, A.; Muthusubramanian, S.; Bhuvanesh, N. Org. Chem. Front. 2017, 4, 124-129. doi:10.1039/c6qo00541a

8. Suresh, R.; Muthusubramanian, S.; Nagaraj, M.; Manickam, G. Tetrahedron Lett. 2013, 54, 1779-1784. doi:10.1016/j.tetlet.2012.11.065

9. Rajaguru, K.; Mariappan, A.; Suresh, R.; Manivannan, P.; Muthusubramanian, S. Beilstein J. Org. Chem. 2015, 11, 2021-2028. doi:10.3762/bjoc.11.219

10. Tilvi, S.; Singh, K. S. Curr. Org. Chem. 2016, 20, 898-929. doi:10.2174/1385272819666150804000046

11. Wipf, P. Chem. Rev. 1995, 95, 2115-2134. doi:10.1021/cr00038a013

12. Shin-ya, K.; Wierzba, K.; Matsuo, K.-i.; Ohtani, T.; Yamada, Y.; Furihata, K.; Hayakawa, Y.; Seto, H. J. Am. Chem. Soc. 2001, 123, 1262-1263. doi:10.1021/ja005780q

13. Dalisay, D. S.; Rogers, E. W.; Edison, A. S.; Molinski, T. F. J. Nat. Prod. 2009, 72, 732-738. doi:10.1021/np8007649 
14. Wilson, Z. E.; Fenner, S.; Ley, S. V. Angew. Chem., Int. Ed. 2015, 54 1284-1288. doi:10.1002/anie.201410063

Angew. Chem. 2015, 127, 1300-1304. doi:10.1002/ange.201410063

15. Joshi, S.; Bisht, A. S.; Juyal, D. Pharma Innovation 2017, 6, 109-117.

16. Fernandes, E.; Costa, D.; Toste, S. A.; Lima, J. L. F. C.; Reis, S. Free Radical Biol. Med. 2004, 37, 1895-1905.

doi:10.1016/j.freeradbiomed.2004.09.001

17. Wang, W.-L.; Yao, D.-Y.; Gu, M.; Fan, M.-Z.; Li, J.-Y.; Xing, Y.-C.; Nan, F.-J. Bioorg. Med. Chem. Lett. 2005, 15, 5284-5287. doi:10.1016/j.bmcl.2005.08.046

18. Reddy, B. A.; Hymavathi, R. V.; Swamy, G. N. J. Chem. Sci. 2013, 125, 495-509. doi:10.1007/s12039-013-0417-7

19. Baranov, M. S.; Lukyanov, K. A.; Ivashkin, P. E.; Yampolsky, I. V. Synth. Commun. 2013, 43, 2337-2342. doi:10.1080/00397911.2012.706350

20. Huong, V. T. T.; Tai, T. B.; Nguyen, M. T. J. Phys. Chem. A 2014, 118, 3335-3343. doi:10.1021/jp500899k

21. Boyd, G. V. Oxazoles and their Benzo Derivatives. In Comprehensive Heterocyclic Chemistry; Katritzky, A. R.; Rees, C. W., Eds.; Pergamon: Oxford, UK, 1984; Vol. 6, pp 177-233. doi:10.1016/b978-008096519-2.00086-2

22. Hartner, F. W., Jr. In Comprehensive Heterocyclic Chemistry; Katritzky, A. R.; Rees, C. W.; Scriven, E. F. V., Eds.; Elsevier: Oxford, UK, 1996; Vol. 3, pp 261-318.

23. Knight, D. W. Oxazole and its Derivatives. In Heterocycles in natural product synthesis; Majumdar, K. C.; Chattopadhyay, S. K., Eds.; Wiley-VCH: Weinheim, Germany, 2011; pp 403-458. doi:10.1002/9783527634880.ch12

24. Revuelta, J.; Machetti, F.; Cicchi, S. Five-Membered Heterocycles: 1,3-Azoles. In Modern Heterocyclic Chemistry; Alvarez-Builla, J.; Vaquero, J. J.; Barluenga, J., Eds.; Wiley-VCH: Weinheim, Germany, 2011; Vol. 2, pp 809-923. doi:10.1002/9783527637737.ch10

25. Jin, Z. Nat. Prod. Rep. 2011, 28, 1143-1191. doi:10.1039/c0np00074d

26. Gulevich, A. V.; Dudnik, A. S.; Chernyak, N.; Gevorgyan, V. Chem. Rev. 2013, 113, 3084-3213. doi:10.1021/cr300333u

27. Perner, R. J.; Koenig, J. R.; DiDomenico, S.; Gomtsyan, A.; Schmidt, R. G.; Lee, C.-H.; Hsu, M. C.; McDonald, H. A.; Gauvin, D. M.; Joshi, S.; Turner, T. M.; Reilly, R. M.; Kym, P. R.; Kort, M. E. Bioorg. Med. Chem. 2010, 18, 4821-4829. doi:10.1016/j.bmc.2010.04.099

28. Ryu, C.-K.; Lee, R.-Y.; Kim, N. Y.; Kim, Y. H.; Song, A. L. Bioorg. Med. Chem. Lett. 2009, 19, 5924-5926. doi:10.1016/j.bmcl.2009.08.062

29. Argade, N. D.; Kalrale, B. K.; Gill, C. H. E-J. Chem. 2008, 5, 120-129. doi:10.1155/2008/265131

30. Merla, B.; Oberboersch, S.; Sundermann, B.; Englberger, W.; Hennies, H. H.; Graubaum, H. Substituted oxazole compounds with analgesic activity. U.S. Patent US7608619B2, Oct 27, 2009.

31. Kean, W. F. Curr. Med. Res. Opin. 2004, 20, 1275-1277. doi:10.1185/030079904125004420

32. Liu, X.-H.; Lv, P.-C.; Xue, J.-Y.; Song, B.-A.; Zhu, H.-L. Eur. J. Med. Chem. 2009, 44, 3930-3935. doi:10.1016/j.ejmech.2009.04.019

33. Desroy, N.; Moreau, F.; Briet, S.; Fralliec, G. L.; Floquet, S.; Durant, L.; Vongsouthi, V.; Gerusz, V.; Denis, A.; Escaich, S. Bioorg. Med. Chem. 2009, 17, 1276-1289. doi:10.1016/j.bmc.2008.12.021

34. Heng, S.; Gryncel, K. R.; Kantrowitz, E. R. Bioorg. Med. Chem. 2009, 17, 3916-3922. doi:10.1016/j.bmc.2009.04.030

35. Copp, B. R. Nat. Prod. Rep. 2003, 20, 535-557. doi:10.1039/b212154a
36. Lack, N. A.; Axerio-Cilies, P.; Tavassoli, P.; Han, F. Q.; Chan, K. H.; Feau, C.; LeBlanc, E.; Guns, E. T.; Guy, R. K.; Rennie, P. S.; Cherkasov, A. J. Med. Chem. 2011, 54, 8563-8573. doi:10.1021/jm201098n

37. Hashimoto, H.; Imamura, K.; Haruta, J.-i.; Wakitani, K. J. Med. Chem. 2002, 45, 1511-1517. doi:10.1021/jm010484p

38. Momose, Y.; Maekawa, T.; Yamano, T.; Kawada, M.; Odaka, H.; Ikeda, H.; Sohda, T. J. Med. Chem. 2002, 45, 1518-1534. doi:10.1021/jm010490l

39. Brown, P.; Davies, D. T.; O'Hanlo, P. J.; Wilson, J. M. J. Med. Chem. 1996, 39, 446-457. doi:10.1021/jm9503862

40. Yang, W. S.; Shimada, K.; Delva, D.; Patel, M.; Ode, E.; Skouta, R.; Stockwell, B. R. ACS Med. Chem. Lett. 2012, 3, 35-38. doi:10.1021/ml200195s

41. Shaw, A. Y.; Henderson, M. C.; Flynn, G.; Samulitis, B.; Han, H.; Stratton, S. P.; Chow, H.-H. S.; Hurley, L. H.; Dorr, R. T. J. Pharmacol. Exp. Ther. 2009, 331, 636-647. doi:10.1124/jpet.109.156406

42. Giddens, A. C.; Boshoff, H. I. M.; Franzblau, S. G.; Barry, C. E., III; Copp, B. R. Tetrahedron Lett. 2005, 46, 7355-7357. doi:10.1016/j.tetlet.2005.08.119

43. Yamada, K.; Kamimura, N.; Kunishima, M. Beilstein J. Org. Chem. 2017, 13, 1478-1485. doi:10.3762/bjoc.13.146

44. Ibrar, A.; Khan, I.; Abbas, N.; Farooq, U.; Khan, A. RSC Adv. 2016, 6, 93016-93047. doi:10.1039/c6ra19324b And references cited therein.

45. Ning, Y.; Otani, Y.; Ohwada, T. J. Org. Chem. 2017, 82, 6313-6326. doi:10.1021/acs.joc.7b00904

46. Lopes, S.; Nunes, C. M.; Fausto, R.; Pinho e Melo, T. M. V. D. J. Mol. Struct. 2009, 919, 47-53. doi:10.1016/j.molstruc.2008.08.014

47. Duan, X.; Yang, K.; Lu, J.; Kong, X.; Liu, N.; Ma, J. Org. Lett. 2017, 19, 3370-3373. doi:10.1021/acs.orglett.7b01305

48. Zeng, T.-T.; Xuan, J.; Ding, W.; Wang, K.; Lu, L.-Q.; Xiao, W.-J. Org. Lett. 2015, 17, 4070-4073. doi:10.1021/acs.orglett.5b01994

49. Xie, H.; Yuan, D.; Ding, M.-W. J. Org. Chem. 2012, 77, 2954-2958. doi:10.1021/jo202588j

50. Rossa, T. A.; Suveges, N. S.; Sá, M. M.; Cantillo, D.; Kappe, C. O. Beilstein J. Org. Chem. 2018, 14, 506-514. doi:10.3762/bjoc.14.36

51. Metzger, J. V. In Comprehensive Heterocyclic Chemistry; Katritzky, A. R.; Rees, C. W., Eds.; Pergamon: New York, NY, USA, 1984; Vol. 6, pp 235-332.

52. Lewis, J. R. Nat. Prod. Rep. 1999, 16, 389-416. doi:10.1039/a802500b

53. Fink, B. E.; Mortensen, D. S.; Stauffer, S. R.; Aron, Z. D.; Katzenellenbogen, J. A. Chem. Biol. 1999, 6, 205-219. doi:10.1016/s1074-5521(99)80037-4

54. Liu, R.; Huang, Z.; Murray, M. G.; Guo, X.; Liu, G. J. Med. Chem. 2011, 54, 5747-5768. doi:10.1021/jm200394x

55. Gallardo-Godoy, A.; Gever, J.; Fife, K. L.; Silber, B. M.; Prusiner, S. B.; Renslo, A. R. J. Med. Chem. 2011, 54, 1010-1021. doi:10.1021/jm101250y

56. Suh, J.; Yum, E. K.; Cheon, H. G.; Cho, Y. S. Chem. Biol. Drug Des. 2012, 80, 89-98. doi:10.1111/j.1747-0285.2012.01371.x

57. Annadurai, S.; Martinez, R.; Canney, D. J.; Eidem, T.; Dunman, P. M.; Abou-Gharbia, M. Bioorg. Med. Chem. Lett. 2012, 22, 7719-7725. doi:10.1016/j.bmcl.2012.09.095

58. Roy, K. K.; Singh, S.; Sharma, S. K.; Srivastava, R.; Chaturvedi, V.; Saxena, A. K. Bioorg. Med. Chem. Lett. 2011, 21, 5589-5593. doi:10.1016/j.bmcl.2011.06.076 
59. Zablotskaya, A.; Segal, I.; Germane, S.; Shestakova, I.; Domracheva, I.; Nesterova, A.; Geronikaki, A.; Lukevics, E. Chem. Heterocycl. Compd. 2002, 38, 859-866. doi:10.1023/a:1020698107686

60. Romagnoli, R.; Baraldi, P. G.; Salvador, M. K.; Camacho, M. E.; Preti, D.; Tabrizi, M. A.; Bassetto, M.; Brancale, A.; Hamel, E.; Bortolozzi, R.; Basso, G.; Viola, G. Bioorg. Med. Chem. 2012, 20, 7083-7094. doi:10.1016/j.bmc.2012.10.001

61. Das, J.; Chen, P.; Norris, D.; Padmanabha, R.; Lin, J.; Moquin, R. V.; Shen, Z.; Cook, L. S.; Doweyko, A. M.; Pitt, S.; Pang, S.; Shen, D. R.; Fang, Q.; de Fex, H. F.; McIntyre, K. W.; Shuster, D. J.; Gillooly, K. M.; Behnia, K.; Schieven, G. L.; Wityak, J.; Barrish, J. C. J. Med. Chem. 2006, 49, 6819-6832. doi:10.1021/jm060727j

62. Schranck, J.; Tlili, A.; Beller, M. Angew. Chem., Int. Ed. 2013, 52 , 7642-7644. doi:10.1002/anie.201303015

63. Vincent, G. Cycloadditions with Stereoselective C-N Bond Formation in Total Syntheses. In tereoselective Synthesis of Drugs and Natural Products; Andrushko, V.; Andrushko, N., Eds.; John Wiley \& Sons: Hoboken, NJ, USA, 2013; Vol. 2, pp $1251 \mathrm{ff}$. doi:10.1002/9781118596784.ssd041

64. Lamberth, C.; Dinges, J. The Significance of Heterocycles for Pharmaceuticals and Agrochemicals. In Bioactive Heterocyclic Compound Classes: Pharmaceuticals; Lamberth, C.; Dinges, J., Eds.; Wiley-VCH: Weinheim, Germany, 2012; pp 1-20. doi:10.1002/9783527664412.ch1

65. Harisha, M. B.; Dhanalakshmi, P.; Suresh, R.; Kumar, R. R.; Muthusubramanian, S.; Bhuvanesh, N. ChemistrySelect 2019, 4, 2954-2958. doi:10.1002/slct.201801543

66. Qin, W.; Long, S.; Panunzio, M.; Biondi, S. Molecules 2013, 18, 12264-12289. doi:10.3390/molecules181012264

67. Dhar, D. N.; Taploo, C. L. J. Sci. Ind. Res. 1982, 41, 501-506.

68. Przybylski, P.; Huczynski, A.; Pyta, K.; Brzezinski, B.; Bartl, F. Curr. Org. Chem. 2009, 13, 124-148. doi:10.2174/138527209787193774

69. da Silva, C. M.; da Silva, D. L.; Modolo, L. V.; Alves, R. B.; de Resende, M. A.; Martins, C. V. B.; de Fátima, Â. J. Adv. Res. 2011, 2, 1-8. doi:10.1016/j.jare.2010.05.004

70. Velik, J.; Baliharova, V.; Skalova, L.; Szotakova, B.; Wsol, V.; Lamka, J. J. Vet. Pharmacol. Ther. 2003, 26, 297-302. doi:10.1046/j.1365-2885.2003.00484.x

71. CCDC deposits 1959141 (4h) and 1959142 (5) contain the supplementary crystallographic data for this article, which can be obtained free of charge from the Cambridge Crystallographic Data Centre.

72. Yang, D.; Yan, K.; Wei, W.; Li, G.; Lu, S.; Zhao, C.; Tian, L.; Wang, H. J. Org. Chem. 2015, 80, 11073-11079. doi:10.1021/acs.joc.5b01637

73. Zhang, G.; Chen, B.; Guo, X.; Guo, S.; Yu, Y. Adv. Synth. Catal. 2015, 357, 1065-1069. doi:10.1002/adsc.201400856

74. Xu, Z.; Ba, M.; Zhou, H.; Cao, Y.; Tang, C.; Yang, Y.; He, R.; Liang, Y.; Zhang, X.; Li, Z.; Zhu, L.; Guo, Y.; Guo, C. Eur. J. Med. Chem. 2014, 85, 27-42. doi:10.1016/j.ejmech.2014.07.072

75. Zhu, D.; Chen, J.; Xiao, H.; Liu, M.; Ding, J.; Wu, H. Synth. Commun. 2009, 39, 2895-2906. doi:10.1080/00397910802691874

76. Jalani, H. B.; Pandya, A. N.; Pandya, D. H.; Sharma, J. A.; Sudarsanam, V.; Vasu, K. K. Tetrahedron Lett. 2013, 54, 5403-5406. doi:10.1016/j.tetlet.2013.07.122

77.Zhu, Y.-P.; Yuan, J.-J.; Zhao, Q.; Lian, M.; Gao, Q.-H.; Liu, M.-C.; Yang, Y.; Wu, A.-X. Tetrahedron 2012, 68, 173-178. doi:10.1016/j.tet.2011.10.074
78. Sinha, S.; Doble, M.; Manju, S. L. Eur. J. Med. Chem. 2018, 158, 34-50. doi:10.1016/j.ejmech.2018.08.098

79. Darji, N. D.; Pasha, T. Y.; Bhandari, A.; Molvi, K. I.; Desai, S. A.; Makwana, M. V. Pharma Chem. 2012, 4, 808-812.

\section{License and Terms}

This is an Open Access article under the terms of the Creative Commons Attribution License (https://creativecommons.org/licenses/by/4.0). Please note that the reuse, redistribution and reproduction in particular requires that the authors and source are credited.

The license is subject to the Beilstein Journal of Organic Chemistry terms and conditions:

(https://www.beilstein-journals.org/bjoc)

The definitive version of this article is the electronic one which can be found at: https://doi.org/10.3762/bjoc.16.178 